
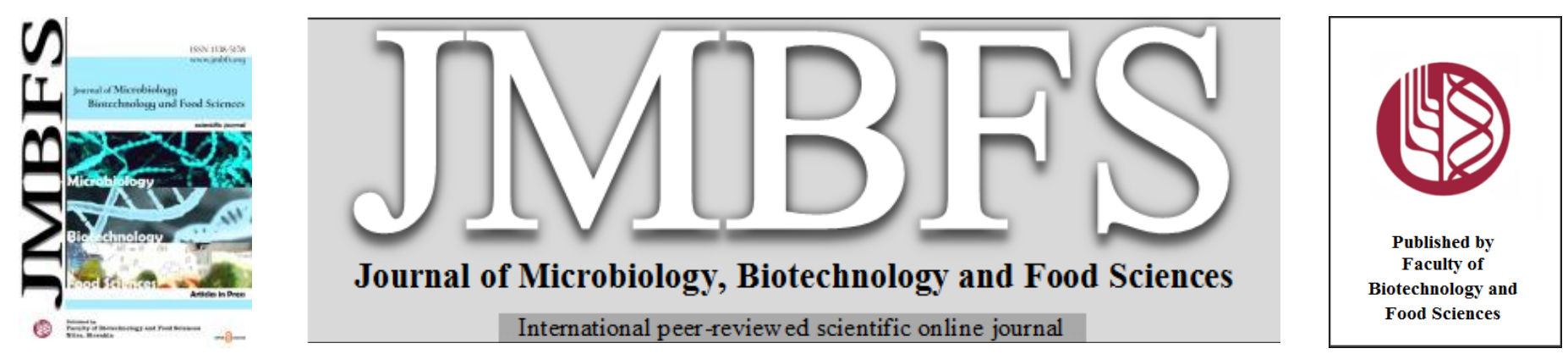

\title{
BIOETHANOL PRODUCTION FROM AGRICULTURAL WASTES BY ZYMOMONAS MOBILIS AND USED IN VINEGAR PRODUCTION
}

\author{
Tabark Hassan Nassir ${ }^{l}$, Shayma Thyab Gddoa Al-Sahlany ${ }^{* 1}$ \\ Address(es): Shayma Thyab Gddoa Al-Sahlany, \\ ${ }^{1}$ University of Basrah, College of Agriculture, Department of Food science. Basra city, 60014, Iraq.
}

*Corresponding author: Shayma.gddoa@uobasrah.edu.iq

https://doi.org/10.15414/jmbfs.3709

\section{ARTICLE INFO}

Received 14. 9. 2020

Revised 10. 6. 2021

Accepted 16. 6. 2021

Published 1. 12. 2021

Regular article OPEN $\partial_{\text {AcCESS }}$

\begin{abstract}
This review paper summarizes the best method for the utilization of agricultural wastes as raw material for the production of bioethanol. Agricultural wastes are rich in sugar and complex carbohydrates that makes it suitable source to carry out the fermentation process. Bioethanol is widely used in industries such as, chemical, pharmaceutical and food for various purposes especially as sterilizer. Carbohydrates are considered as the renewable sources and the primary material for the production of bioethanol. Microorganisms such as some species of yeasts and bacteria are capable to ferment carbohydrates and convert it into ethyl alcohol. However, the ability of these micro-organisms differs with respect to the production of ethanol and this research we study the possibility of producing bioethanol from the bacterium Zymomonas mobilis. One of the major industrial aspects of ethanol is the production of vinegar and there are several methods that could be utilized for its production from ethanol. Studies have reported that Zymomonas mobilis has 5-10 times more capability to produce bioethanol as compared with Saccharomyces cerevisiae. Therefore, this study has been done to highlight the possibilities of production of bioethanol from Zymomonas mobilis
\end{abstract}

Keywords: Zymomonas mobilis, bioethanol, agricultural wastes, vinegar

\section{INTRODUCTION}

Bioethanol is considered as a renewable and clean source of energy as its production is dependent on the conversion of biomass, mainly agricultural crops such as corn and sugarcane; oils such as soyabean or plam oil and animal fats. Since it can be utilized for multipurpose works, several countries like USA, Brazil, Germany, Sweden, Canada and India have used this bioethanol for lightning, driving of vehicles, managing generators; etc. (Demirbas, 2009). The production of bioethanol has also helped in creating new economic opportunities for the countries involved in export of oil as well as developing countries. Renewable energy sources that utilize natural resources produces energy that is free from airpolluting gases (Leung $\boldsymbol{e t} \boldsymbol{a l}$., 2010). In addition to it, bioethanol will reduce dependence on imported oil, reduce greenhouse gas emissions and other pollutants, and stimulate the global economy by increasing the demand for agricultural products (Acharya and Perez-Pena, 2020). The natural sources i.e. renewable are economically cheap, available in abundance and could be regenerated. Therefore, these renewable resources such as, agricultural residues, tree and wood residues, algae; etc. can be used for the generation of energy and also, as an alternative to costly raw materials. Bioethanol has grabbed the market within few years worldwide and also has established as an individual big industry. However, there exists rivalry for bioethanol as human food, since it's a renewable source of energy (Shah and Sen, 2011). Therefore, researchers have reported studies to produce bioethanol from agricultural wastes, in order to avoid its competition with human food. In addition to this fact that ethanol production of waste has a significant positive impact on the environment in terms of disposing waste and convert into bioethanol, as well as the environmental pollution was resulting from the combustion of ethanol is less compared to those released from fossil fuels (Nakshoo and Ebrahim, 2013). Ethanol is produced by the process of fermentation carried out by microorganisms under anaerobic conditions. Fermentation is carried out on raw materials rich in carbohydrates, especially hexose sugar, for example, glucose, most commonly glucose. Therefore, primary raw materials that contains high level of glucose are the best for converting it into ethanol (Kumari and Singh, 2018; Choi et al., 2019). Bioethanol is currently produced mainly by using Saccharomyces cerevisiae due to its tolerance of low $\mathrm{pH}$ and high concentration of ethanol, in addition to Zymomonas mobilis bacteria, which has higher ethanol productivity due to its fermentation of hexose sugars such as glucose, fructose and sucrose (Zhang et al., 2019). Ethanol is one of the most important organic chemicals, due to its wide applications in industries (food pharmaceuticals, and chemicals), and also used as solvent for materials utilized in the manufacture of perfumes, medicines, and make-up. It is also used as a base material for the manufacture of vinegar, an organic acid used for the human consumption. Vinegar is produced by a double-fermentation process, where agricultural products containing starch or sugars are used as raw materials Alcoholic fermentation comes first, followed by acetic acid fermentation. The process of producing vinegar from ethanol can be summarized according to the equation (Bhat et al., 2014).

\section{Ethanol-producing microorganisms}

Many microorganisms have the ability to produce ethanol, but they differ in their ability to tolerate certain concentrations of ethanol, as well as the sugars that they ferment. Some of them have the ability to ferment lactose and others ferment glucose, fructose and sucrose. Others have the ability to decompose cellulose into simple sugars and produce ethanol. There are also types that have the ability to produce ethanol from quintet sugars.

\section{Yeasts}

Yeasts have the ability to produce ethanol and this has received great attention from researchers. Presently, ethanol is produced mainly from Saccharomyces cerevisiae. Studies have also reported the utilization of Saccharomyces carlsbergensis for the production of ethanol are Saccharomyces carlsbergensis. Past studies have found that Saccharomyces cerevisiae has the ability to produce more ethanol than other yeasts species (Jwad and AI-Haidari, 2017). In addition to some species belonging to the genus Kluyveromyces yeast and family Saccharomycetaceae, is considered one of the yeasts that can destroy alcoholic products and these types are $K$. marxianus, $K$. fragilis, $K$. lactis. As these yeasts have the ability to convert lactose directly into ethanol and are isolated from dairy products (Fonseca et al., 2008). It has been found that $K$. marxianus has the ability to ferment D-xylose directly into ethanol (Margaritis and Bajpai, 1982). There is 
also Candida yeast, which belongs to the family Cryptococcaceae, and this contains two species, i.e. C. pseudotropicalis and C. kefyr that have the ability to produce ethanol and the latter is found in cow's and goat's milk. One of the studies have reported that it gives an alcoholic flavor to the milk because of the lactose fermentation into ethanol and carbon dioxide (Fonseca et al., 2008). It has been shown that $C$. Kefyr has the ability to produce ethanol from lactose better than Saccharomyces cerevisiae (Kamini and Gunasekaran, 1987). Interest in Schwonniomyces occidentolis, which belongs to the family of Saccharomycetaceae, has increased in recent years due to its good fermentation properties, strong hydrolysis system, fermentation of a wide range of carbohydrates, as well as its tolerance to low concentrations of ethanol (Horn $\boldsymbol{e}$ al., 1992). S. occidentolis is capable to ferment soluble starch directly into ethanol with a high efficiency of up to $95 \%$, as this yeast possesses all the enzymes necessary to decompose the starch and convert it into fermented sugar (Calleja $\boldsymbol{e t}$ al., 1982).

\section{Bacteria}

Research and studies have been directed at the use of several species and strains of bacteria to produce bioethanol, which are characterized by their ability to ferment carbohydrates. In general, the bacteria take minutes to ferment the carbohydrates compared to the yeast that takes hours (Dien et al., 2003; Rutz and Janssen, 2007). Lactic acid bacteria (LAB), that are considered for heterogenous fermentation are capable the ability to ferment carbohydrates and produce ethanol, especially Leuconostoc. In addition to the rapid fermentation of carbohydrates, bacteria are also present in natural fermentable substrates as enlisted in Table 1. Soleimani et al. (2017) has reported the possibility of producing ethanol from the bacteria Lactobacillus plantarum M24, Lactobacillus sakei and Weissella viridescens LB37 by using agricultural residues (corn, corn residues and pine leaves). The results of the study proved that L. plantarum M24 is the most efficient type of bacteria in ethanol production from agricultural waste.

Table 1 Microorganisms for the production of bioethanol and optimum fermentation conditions for high ethanol production

\begin{tabular}{|c|c|c|c|}
\hline Microorganism & $\begin{array}{l}\text { Fermentable } \\
\text { substrates }\end{array}$ & $\begin{array}{l}\text { Fermentation } \\
\text { conditions }\end{array}$ & $\begin{array}{l}\text { Ethanol } \\
\text { tolerance }(\mathrm{g} / \mathrm{L})\end{array}$ \\
\hline Saccharomyces cerevisiae & $\begin{array}{l}\text { Glucose, fructose, } \\
\text { maltose, sucrose }\end{array}$ & Anaerobic, $30-37^{\circ} \mathrm{C}$ & 150 \\
\hline Schizosaccharomyces pombe & $\begin{array}{l}\text { Glucose, fructose, } \\
\text { maltose, sucrose }\end{array}$ & Anaerobic, $30-35^{\circ} \mathrm{C}$ & - \\
\hline Kluyverommyces marxianus & Glucose & Anaerobic, $40-45^{\circ} \mathrm{C}$ & - \\
\hline Candida shehatae & Glucose, xylose & Microaerophilic, $20-31^{\circ} \mathrm{C}$ & $30-45$ \\
\hline Pichia stipites & Glucose, xylose & Microaerophilic, $26-35^{\circ} \mathrm{C}$ & $35-47$ \\
\hline Pachysolen tannophilus & $\begin{array}{l}\text { Glucose, xylose, } \\
\text { glycerol }\end{array}$ & Microaerophilic & $37.5-75$ \\
\hline Zymomonas mobilis & $\begin{array}{l}\text { Glucose, fructose, } \\
\text { sucrose }\end{array}$ & Anaerobic, $30^{\circ} \mathrm{C}$ & 100 \\
\hline Clostridium thermocellum & Glucose, cellulose & Anaerobic, $55-65^{\circ} \mathrm{C}$ & $10-30$ \\
\hline $\begin{array}{l}\text { Clostridium } \\
\text { thermosaccharolyticum }\end{array}$ & Glucose, xylose & Anaerobic, $60^{\circ} \mathrm{C}$ & $<30$ \\
\hline
\end{tabular}

Ethanol can also be produced from thermophiles, This group of bacteria have the ability to rapidly ferment cellulose without the need of enzymes, and it does not ferment ethanol homogeneously and also does not tolerate high concentrations of bioethanol, including, anaerobic bacteria include Thermoanaerobacterium, Thermoanaerobacter saccharolyticum ethanolicus,

Thermoanaerobacter mathranii, Clostridium thermocellum, Caldicellulosiruptor bescii and the facultative anaerobic bacteria Geobacillus Olmoglucidasiusius (Olson et al., 2015). Figure 1 shows the metabolic pathway of the ethanolproducing microorganisms. Some bacteria have the ability to convert glucose into pyruvic acid via the Entner-Doudoroff (ED) pathway as such for Zymomonas spp. while others via the EMP pathway that converts pyruvic acid to ethanol.

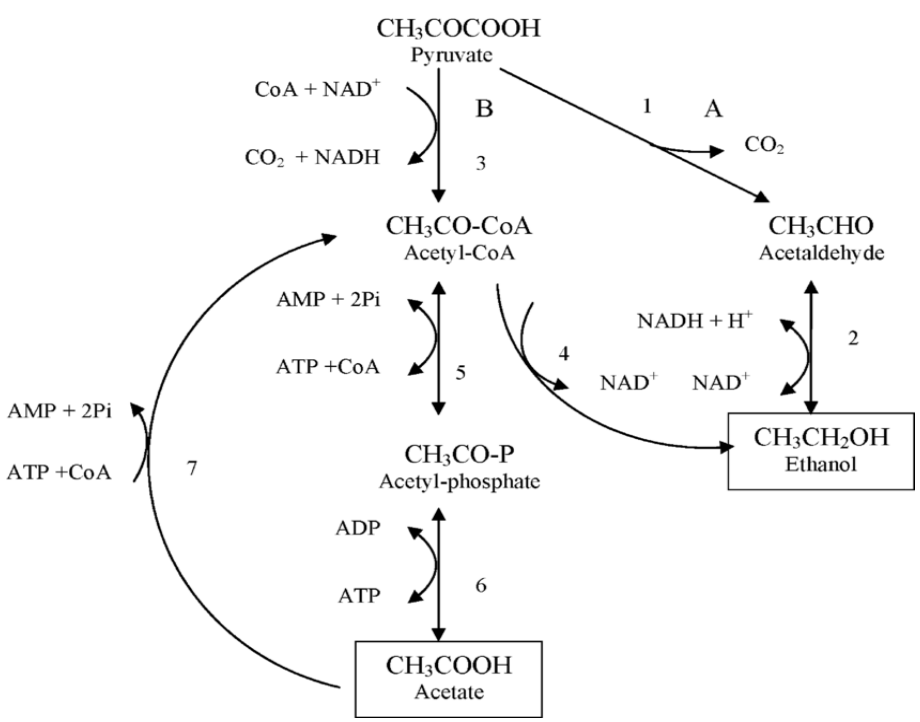

Figure 1 Shows the fermentation of glucose to ethanol by yeasts and bacteria species. The reactions shown are from the pyruvic acid phase of the final products. (A) Yeasts; (B) Bacteria (1) pyruvate decarboxylase. (2) alcohol dehydrogenase. (3) pyruvatedehydrogenase or pyruvate formatelyase (4) acetaldehyde/alcohol dehydrogenase (5) phosphotransacetylase (6) acetate kinase (7) AMP-forming acetyl-CoA synthetase (Boumba et al., 2008).

\section{Zymomonas mobilis}

Interest in this bacterium has increased all over the world due to its importance in the production of ethanol. Zymomonas mobilis includes two subspecies under the type, Z. mobilis subsp. mobiles and Z.mobilis subsp.pomacea and was firs discovered in 1911 by Barker and Hillier (Swings and De Ley, 1977). Selective anaerobic bacteria, negative as per the Gram-stanning method, grow at a temperature of $25-31^{\circ} \mathrm{C}$ and their growth, decreases at $15^{\circ} \mathrm{C}$. The bacteria $Z$ mobilis has been used in the production of ethanol significantly during the past years and there are results from repeated studies that this bacterium was replaced with $S$. cerevisiae in bioethanol production, It was first isolated from alcoholic beverage in South Africa. In 1979, the Australian group Rogers P.L (Baratti and Bu'Lock, 1986) published the first research on the potential of Z. mobilis for the production of ethanol.

Bai et al. (2008) observed that Z. mobilis are more suitable for producing alcohol than yeast because it has better properties compared to yeast. Moreover, some researchers have mentioned that the productivity of $Z$. mobilis from alcohol was 5 $10 \%$ higher than that of yeasts. This is due to its high ability to withstand the concentration of ethanol, as it bears more than $16 \%$, tolerates high concentrations of sugar in the fermentation solution, and multiplies slowly during the fermentation process. Thus, consuming less energy than the yeast and does not need to provide additional quantities of oxygen during the fermentation process (Bochner $\boldsymbol{e t}$ al., 2010; Rutkis et al., 2013).

The rate of ethanol production is affected by several factors such as the acidity, temperature, and concentration of the substrate in the fermentation medium. It has been observed in some studies the possibility of bacterial growth within temperature range of $25-42^{\circ} \mathrm{C}$ (Farkas et al., 2020). Other studies have found that some strains grow at $38^{\circ} \mathrm{C}$ but did not grow at a temperature of $40^{\circ} \mathrm{C}$, and fermentation can occur between temperatures of $30-36^{\circ} \mathrm{C}$ without any change in the ethanol yield (Deanda et al., 1996). Z. mobilis is the only microorganism that ferments glucose anaerobically using the Entner-Doudoroff (ED) pathway instead of the Embden-Meyerhoff-Parnas (EMP) pathway (Fig. 2) (Conway,1992). 


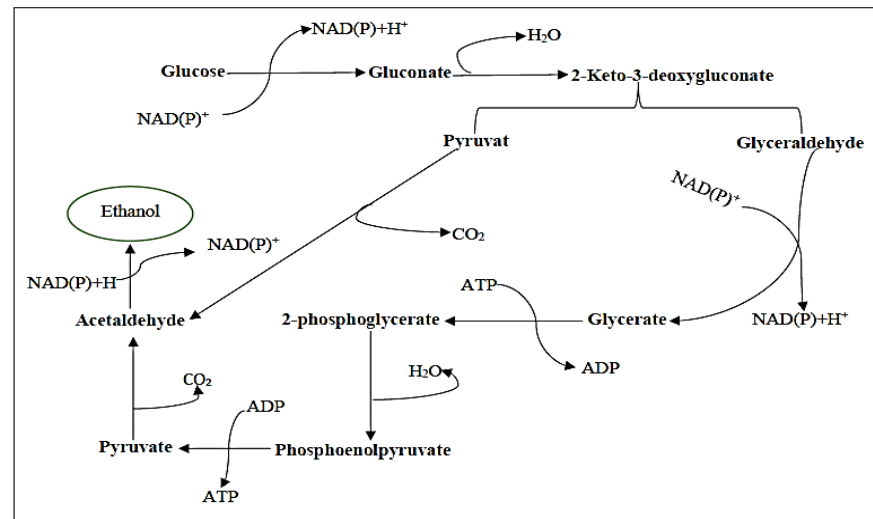

Figure 2 The metabolic pathway of Z. mobilis to produce bioethanol through fermentation of glucose.

\section{Bioethanol properties}

Ethanol is an organic chemical compound classified within alcohols produced by fermentation of carbohydrates extracted from plant materials and with the development of advanced technology, cellulosic materials, such as trees and herbs, also used as material's subject to its production (Shah et al., 2011). It has a partial formula of $\mathrm{C}_{2} \mathrm{H}_{6} \mathrm{O}$ (Stewart et al., 1983).

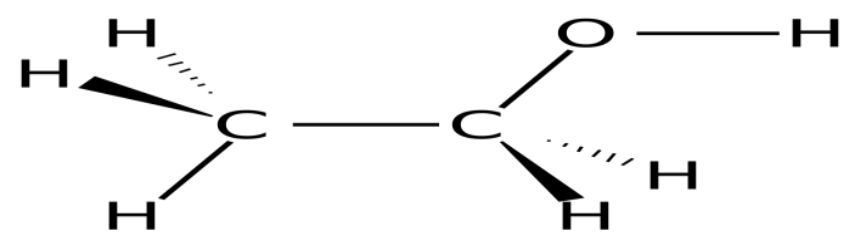

Figure 3 The chemical composition of ethanol.

It is a volatile, and flammable liquid substance, with a distinct odor. It is a polar compound, as it has the ability to create a hydrogen fusion between its molecules. Its boiling point reaches $78.32^{\circ} \mathrm{C}$ (Table 2). It has the ability to dissolve in polar solvents such as water, as it works to form hydrogen bonds with water molecules. It can be mixed with water, glycerin, acetone, carbon tetrachloride, benzene, chloroform, and many other types of organic solvents. Ethanol is used as a solvent, antimicrobial, disinfectant, and fuel. Ethanol produced from fermentation is used as an additive in automobile fuel to reduce emissions. (Logsdon, 2004).

Table 2 General properties of bioethanol produced from microorganisms

\begin{tabular}{ll}
\hline Properties & Value \\
\hline Freezing point $\left({ }^{\circ} \mathrm{C}\right)$ & -114.1 \\
\hline boiling temperature $\left({ }^{\circ} \mathrm{C}\right)$ & 78.32 \\
\hline Density $(\mathrm{g} / \mathrm{mL})$ & 0.7893 \\
\hline Refractive index $\mathrm{nD} / \mathrm{t}, 20-30^{\circ} \mathrm{C}$ & 0.000404 \\
\hline Viscosity $20 \mathrm{C} \mathrm{mPa} \cdot \mathrm{s}(\mathrm{cP})$ & 1.17 \\
\hline Thermal conductivity $20^{\circ} \mathrm{C}(\mathrm{W} /(\mathrm{m} \cdot \mathrm{K})$ & 0.170 \\
\hline
\end{tabular}

\section{Applications of bioethanol}

Ethanol is widely used compound in daily life, either for personal / home use, or for cooking, lighting, heating and steam production. In addition to it, ethanol is also used for the production of vinegar and various types of alcoholic drinks. Alternatively, in the field of scientific research, drug manufacturing, and others, as ethanol is used as an active substance in some medicinal products that are taken orally by injection, or by topical use, including drugs that are taken by inhalation. Ethanol is used as primary solvent in pharmaceutical industries (Gupta et al., 2016). The application of ethanol is personal care products is due to the fact that limited concentrations of ethanol helps to cleanse the skin, it is used as a preservative and also helps to homogenize the components of the cosmetic product, and its presence in hair sprays helps the spray to stick to the hair, due to its germicidal properties, it is used in mouthwashes. It is used in disinfectants and sterilizers, as ethanol has anti-bacterial, anti-fungal and anti-viral properties. It is also used in house-hold products, such as paints, where ethanol being a solvent helps the mixing of paint's ingredients. It is also use as fuel for cars and engines after it has been mixed with other materials. The global consumption of ethanol as fuel for car engines is estimated at about 30 million (Fonseca et al., 2008). Ethano can be used as a unit in engines or mixed with gasoline in any percentage. Most of today's automotive gasoline engines can run on a mixture of up to 15\% bioethanol / gasoline (Shah et al., 2011). One of the reasons that led to the tendency to use ethanol as a fuel for cars is because it can be produced from agricultural and cellulosic waste that can be collected from wood, weeds, and local waste (Gupta et al., 2016).

\section{Classification of bioethanol into four generations:}

1- Fuel produced from edible plants such as sugar, starch and corn.

2- Fuels produced from inedible plants, such as wood and cellulose.

3-Fuel produced from algae and other microorganisms.

4- Bioethanol (gasoline) produced from vegetable oil and biodiesel.

\section{The economic importance of producing ethanol from agricultural waste}

As the importance of bioethanol has been observed widely, its global production is expected to increase in the coming years due to increased investment, economic policies, and the desire to produce bioethanol, or fuel alcohol, and to significantly remove carbon from energy, thus mitigating the negative effects of greenhouse gas emissions from fossil fuels, and restricting climate change on a global level. For this reason, new distilleries would be established in the coming years, with production expected to exceed 110 billion liters of ethanol by 2023 (Figure 3) (Basso et al., 2019). In addition to its use in multiple industries many paths have been developed to produce the raw materials as a renewable source (de Moraes and Zilberman, 2014; Hoogendoorn and van Kasteren, 2010). Brazil and USA have been reported to be the highest bioethanol producing countries in the world Brazil has been producing ethanol from sugarcane since 1975 for use as cars fuel while, the United States produces, ethanol from corn, and ethanol produced from sugar cane and corn accounts for more than $90 \%$ of the total production of bioethanol in the world (Logsdon, 2004). Many countries are using bioethanol to reduce their dependence on petroleum fuels. The United States, for example, is seeking to reduce its dependence on oil by $20 \%$ in 2017 and to replace it with the use of bioethanol. Access to renewable energy has become one of the basics for most countries, which have been sought considering the environmental and economic crises and problems the world has witnessed. Which led to the use of all the energies of these countries in order to obtain cheap energy through relying on various production sources, including biofuels, which is one of the fastest growing renewable energy sources in many countries, and the actual and projected production of biofuels worldwide could be observed during the year 2006-2030.

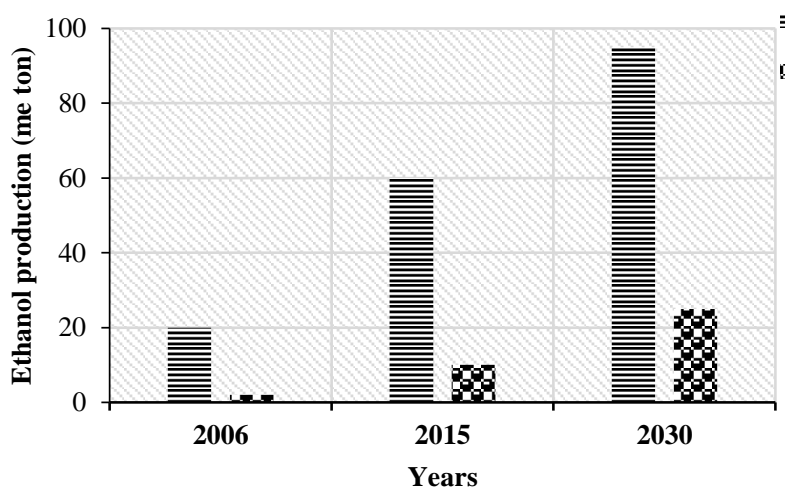

E Ethanol a Biodieset

Figure 3 Actual and projected annual production of bioethanol worldwide during the year 2006-2030 (World energy outlook, 2006).

Agricultural crops rich in sugar and starch content are used as raw material for the production of bioethanol (Kumari and Singh, 2018). These raw materials may include sweet corn, wheat, wheat straw, rice, barley, potatoes, sugar residues, i.e. dates and molasses and forest residues. Therefore, the ethanol production process is an economical process when using agricultural waste, in addition to being ecofriendly, Agricultural wastes are considered to be a heavy burden on the environment, mostly due to its improper ways of disposal. Larger amounts of agricultural waste leads to greater health, environmental and economic damage. Farmers dispose of it in a way that is harmful to the environment, especially by burning it, which leads to an increase in environmental pollution (Abdel-Shafy and Mansour, 2018).

\section{Extraction of bioethanol}

Ethanol is extracted from the fermentation medium through the distillation process to obtain ethanol at a concentration of $96 \%$, through separation process the separation is done because of the difference in the boiling points of the different materials present in the fermentation medium, as other compounds other than ethanol are produced in addition to water. This difference in boiling points plays an important role in the separation process, as the boiling point of ethanol is $78.3^{\circ} \mathrm{C}$. The separation is carried out using distillation devices designed to extract 
ethanol and obtain its highest concentration (Li et al., 2017). The distillation apparatus used to extract ethanol as the process of heating the solution to the boiling point, then the vapors pass through a cooling device called a condenser, and then the liquid that condenses is collected in a special beaker and due to the difference in the boiling point of ethanol and water. The ethanol evaporates and is separated first.

\section{Estimation of bioethanol}

Nakshoo et al. (2013) reported that several techniques have been utilized for estimation of ethanol in solutions. Indicated the use of a high-performance liquid chromatography (HPLC) device, using the EH-002 column, in order to obtain high accuracy in determining the amount of ethanol. The basis of the interaction of monochromatic light with the particles in the sample and scattering a small portion of the photons and the occurrence of vibration, and the readings appear in the form of diagrams (Shih, 2010). In addition to the use of infrared spectroscopy, the quantitative analysis of optical spectroscopy depends on Beer-Lambert's law, which states that there is a linear relationship between the amount of light absorbed by the sample and the concentration of the material. Ethanol is estimated using wavelengths of 1200 and $950 \mathrm{~cm}^{-1}$. The researcher Tonelli (2009), reported that using a GLC liquid gas chromatography device, which is characterized by high analysis speed and gives high accuracy in measuring GLC, is currently used as a standard procedure for analyzing beer in the United States and it is the most common method for estimating ethanol and blood (Curry et al., 1966).

Researchers Wang et al. (2003) used GC to estimate ethanol in alcoholic beverages, as the sample was directly injected into the GC device after adding an appropriate amount of acetonitrile solution. This method took less than 8 minutes to obtain a result since the sample was introduced. There is an enzyme oxidation method using alcohol dehydrogenase that is added to the dichromate oxidation. Gas chromatography is the most widely used method as it gives results in a faster mode. The dichromate oxidation method is the simplest and most suitable for measuring the concentration of ethanol if the estimation is required for the purpose of research such as selecting a high-yielding strain, developing the bioethanol production process, monitoring the process and controlling the production of alcoholic beverages, and the determination of ethanol in clinical samples. In this method, the ethanol solvent is first extracted from the fermentation medium, after which it is measured by the method of dichromate oxidation. When ethanol is present in the aqueous solution, the chromium ions oxidizes ethanol and then the color changes from orange to green (Seo et al., 2009). The chromic acid method, using a spectrophotometer, was used to measure the absorption at a wavelength of $584 \mathrm{~nm}$ to determine the ethanol concentration because of the standard curve of absolute ethanol (Caputi et al., 1968).

\section{Ethanol production from agricultural wastes}

Agricultural wastes are dumped in wrong ways which creates enormous amount of environmental pollution and also, poses negative impacts on human as well as animal health. Now, agricultural waste is used in many industries, the most important of which is the production of ethanol, which has a major economic role at the present time for its uses (Abdel-Shafy and Mansour, 2018). Many studies have been conducted on the possibility of producing ethanol from agricultural waste, and some countries have produced ethanol from agricultural waste instead of using crops of nutritional importance. Recent research includes the production of ethanol from potato skins left over from the food industry. More recently, bioethanol has been produced by using potato residues, which is a common product in the food industry (Huang et al., 2015). In Finland, about 1.5 million kilograms of potato waste are used annually to produce ethanol (Kumari and Singh, 2018). In past study Chandra et al. (2013) who reported, the possibility of producing ethanol from orange peels as agricultural residues by performing the hydrolysis of orange peels, which are characterized by containing a high amount of carbohydrates and by using Z. mobilis bacteria. Kumar et al. (2011) has quoted that India is the largest banana producing country and economically, it is cheap. Ethanol could be produced from banana and banana peels using Saccharomyces cerevisiae. In a study, rice husks (straw) were treated with different physical and chemical methods, and then the cellulose enzyme was added for the purpose of analyzing sugars and producing bioethanol using Saccharomyces cerevisiae (Kumar et al., 2020). Dates are one of the inexpensive sources and are available in large quantities. Great efforts have been made to take advantage of the surplus of poor-quality dates in addition to the fallen dates in the production of bioethanol. It is known that Iraq is distinguished by its abundant production of dates of various kinds, and through researches it has been found that the Zuhdi date variety is distinguished by its high sugar content compared to other varieties, as well as its abundance of production and its cheapness (Louhichi et al., 2013). Therefore, it was used in the production of bio-ethanol. The total concentration of sugar in dates ranges between $63-68 \%$, most of which are in the form of glucose and fructose in roughly equal quantities and are found in small quantities in the form of sucrose. Dates also contain a percentage of minerals, vitamins and nitrogen, which makes it a suitable raw material for the fermentation process, as these elements are essential for the growth of microorganisms.
One of the studies has shown that conducted, the use of small-sized and low-quality dates could be used as a raw material for the production of bio-ethanol, as the dates are washed. Dates are first washed and then are removed from them, the pure date juice is produced, the concentration of sugar in the juice is adjusted, and the best yield of ethanol is found at a concentration of $18 \%$ when using S. cerevisiae yeast for production (Zohri, 2000). The concentration of date juice plays an important role for ethanol produced from microorganisms. Taouda et al. (2017) reported a study of the majority of the substrate is converted into bioethanol (88\%). This is for the use of scrap dates as fermentation substrate. Damaged dates and their residue amount to $10-50 \%$ of the total annual production of dates, and the use of these dates and waste led to a decrease in the cost of ethanol production from 0.34-0.68 US dollars per liter of ethanol (Taghizadeh-Alisaraei et al., 2019). Spoiled fruits were used as waste products to produce bioethanol. Grapes are an important fruit found in all parts of the world, used for food and wine production. In China, the total annual production of grapes is around 5,000,000 tons (Guo, 2003). The damaged grapes were used in the production of bio-ethanol, in addition to the remainder of the juice industry. Grape and beer production residues are bagasse. Chemical and enzymatic analyzes of grape dregs revealed the presence of beer quantities of fermented carbohydrates that are preserved after the grapes are pressed. Grape bagasse is the fibrous material that remains after extracting the juice from the grapefruit. The grape bagasse is separated from the grape juice before fermentation of the white wine. As the wine industry produces large quantities of bagasse annually, the potential environmental impact of grape bagasse is a growing concern and grape bagasse is a waste product of little economic value. The researcher proved that it is possible to obtain a relatively high amount of glucose when carrying out acidic and enzymatic hydrolysis of these wastes (Korkie et al., 2002).

The researcher Raikar (2012) reported a study of ethanol production from spoiled grapes, as the researcher collected grapes and grapes waste from grocery stores, the sugar concentration in these residues was approximately $18-16 \%$, and they obtained the highest production of ethanol at this concentration and by using Saccharomyces cerevisiae. Molasses is one of the most used materials in the production of ethanol because it contains a high percentage of sucrose. Microorganisms, the most important of which is Saccharomycse cerevisiae, which easily converts sucrose into glucose and fructose in the initial fermentation stage by the enzyme invertase located between the yeast cell wall and the cell membrane, by using molasses. Molasses are diluted, it to the required concentration of sugar and adjusting the appropriate $\mathrm{pH}$ for fermentation (Manoochehri et al., 2020). 75\% of the molasses produced in the world comes from sugar cane that grows in tropical climates in Asia, South America and Africa, while the rest comes from sugar beets that grow in Europe and North America in the first place, and the study proved that the best yield of ethanol is from molasses when using yeast. Saccharomyces cerevisiae at $30^{\circ} \mathrm{C}, \mathrm{pH}$ equal to 5 , and a dry matter concentration of $16 \%$ of molasses (Nakshoo and Ebrahim, 2013).

Cazetta et al. (2007) found that fermentation of sugar cane molasses using Z. mobilis bacteria are best for producing a higher amount of ethanol $(200 \mathrm{~g} /$ L). The treatment and purification of molasses led to a decrease in the yield of ethanol compared with untreated molasses (Raharja et al., 2019).

\section{Vinegar production from ethanol}

The vinegar industry is one of the important industries, as the global market needs about more than 3 million tons annually. It and vinegar are used in many medical and pharmaceutical industries and in antibiotics, as well as in the manufacture of plastics, dyes, pesticides and the fiber industry. Vinegar has been known since $5000 \mathrm{BC}$, and ancient Rome used it to preserve food, either alone or by adding salt to it. Vinegar is known as a liquid substance made from sugary or starchy substances resulting from the process of converting ethyl alcohol to acetic acid by using acetic acid bacteria and includes species of the genera Acetobacter and Gluconobacter. Vinegar can be produced from any alcohol. However, it is produced from alcoholic apple juice cider, as well as from grape juice or other fruit juice.

Vinegar is also produced from a mixture of pure alcohol in water and it is called distilled vinegar. Vinegar is used as a flavoring and taste material in various salads and other foods as well as in the manufacture of pickles as it is considered a good preservative as it can be added to meat and vegetables and thus can be preserved without cooling any degree. Thus, it can be preserved without cooling at room temperature for several years.

Acetic acid bacteria have the advantage of being forced air and differ from the rest of the aerobic bacteria in that they do not completely oxidize the electron-donor materials to carbon dioxide and water, so they convert ethanol (ethyl alcohol) as an electron donor and oxidize to acetic acid, which accumulates in the medium (La China et al., 2018). The acetic acid bacteria have the advantage of tolerating acidity and will not be killed by the acidity they are working on producing (Yagnik et al., 2018). It requires a large amount of oxygen to produce vinegar. It must provide adequate ventilation in the middle to complete the production process. The chemical reaction leading to the production of acetic acid. Acetic acid is an organic acid with the chemical formula $\mathrm{CH}_{3} \mathrm{COOH}$ and a molecular weight of 60,052 Dalton, and it is miscible with water (Soto et al., 2019). Vinegar has a bactericidal 
effect, and Table 3 shows the minimum level of inhibiting some types of microorganisms by using vinegar. The effect is due to several reasons, including it works to reduce $\mathrm{pH}$ as most of the bacteria that cause human diseases grow in an environment of neutral acidity and it also has the ability to dissolve fats in the membrane (Halstead et al., 2015). The bacterial cell, in addition to its ability to induce a change in protein composition (dentition)

Table 3 The minimum level of inhibition of some types of microorganisms by using vinegar.

\begin{tabular}{lll}
\hline Microorganisms & $\begin{array}{l}\text { pH } \\
\text { value }\end{array}$ & Minimum discouragement \% (MIC) \\
\hline Aspergillus niger & 4.1 & 0.29 \\
\hline Bacillus cereus & 4.9 & 0.04 \\
\hline Bacillus mesentericus & 4.9 & 0.04 \\
\hline Phytomoas phaseoli & 5.2 & 0.02 \\
\hline Saccharomyces cerevisiae & 3.9 & 0.59 \\
\hline Salmonella spp. & 4.9 & 0.04 \\
\hline Staphylococcus aureus & 0.5 & 0.03 \\
\hline
\end{tabular}

Studies have reported that that adding vinegar to food reduces food poisoning cases at a concentration of $0.1 \%$. It was sufficient to inhibit the growth of all bacterial strains, and studies indicated that industrial vinegar is the most effective. Among its other uses, it is used for preserving food for its ability to kill germs, as well as a flavor-gaining substance, and it is preferred over salt in preserving meat as it increases its tenderness while salt increases the consistency of meat (Kuda et al., 2013).

\section{Vinegar production methods}

Distilled vinegar is produced by using ethanol, and the vinegar manufacturing process goes through two stages:

1- Alcoholic fermentation: Sugar gets converted to ethanol by yeasts. $\mathrm{C}_{6} \mathrm{H}_{12} \mathrm{O}_{6} \longrightarrow 2 \mathrm{C}_{2} \mathrm{H}_{5} \mathrm{OH}+2 \mathrm{CO}_{2}$

2- $\quad$ Acetic acid fermentation: Ethanol gets converted to acetic acid by bacteria through enzymatic under aerobic condition, The following equation represents the two stages of fermentation.

$2 \mathrm{C}_{2} \mathrm{H}_{5} \mathrm{OH}+\mathrm{O}_{2} \longrightarrow \mathrm{CH}_{3} \mathrm{COOH}+\mathrm{H}_{2} \mathrm{O}$

Vinegar can be manufactured using different fermentation methods. These methods basically depend upon the conditions provided for oxidation of ethanol. Another method to carry out the fermentation process is the submerged method, in which fermentation occurs within 30 hours. The fermentation take place in aerobic conditions, as the acetic acid bacteria oxidize the ethano aerobically to acetic acid, and every 1 gram of ethanol gives 1.26 grams of acetic acid and the resulting vinegar is white in color (Matloob and Hamza, 2013). There are three different processes used to produce vinegar.

\section{Orleans Method}

It is the original method and is still used in France. In this method, wine is placed in a large jar superficially to ensure that the liquid is exposed to the air in sufficien quantity. The acetic acid bacteria are placed as a slimy layer on the surface of the liquid and this method is inefficient because the only place where the bacteria are in contact. However, this method is not efficient because the only place where bacteria are in contact with the liquid and the air is the surface of the liquid only (Mas et al., 2014)

\section{Trickle Method}

In this method, the contact between bacteria, air and material can be increased by distilling the alcoholic liquid over wood shavings in a container or column and passing a stream of air towards the top of the container. Bacteria grow on the surface of sawdust, thus their exposure to liquid and air maximum. The vinegar generator is called the "vinegar generator" and the process is called the German process. It is carried out using a continuous production technique. The sawdust used in the production of vinegar can have a lifespan of 5-30 years, depending on the type of alcoholic liquid used in the process. This method is considered one of the fastest methods of producing vinegar. The vinegar generators are of different sizes and shapes, as the diameter of the device can reach 15 feet. The Acetobacter aceti bacteria present on the surface of the liquid and sawdust oxidize the alcoho to acetic acid, and then the acetic acid collects in the collection room below the generator and is collected periodically from the device. The oxidation process carried out by the bacteria by converting the bacteria into acetic acid produces heat from it, so the vinegar generator is equipped with a cooling room to maintain a temperature between $25-30^{\circ} \mathrm{C}$ (Vidra and Németh, 2018)

\section{Bubble Method}

A submerged or submerged farm is used in a similar way to produce antibiotics or enzymes with high ventilation and more efficiently than that used in the production of antibiotics. The production mode is of a continuous type and the alcoholic liquid is added at a rate equal to the rate of removal of the vinegar formed. The production mode shall be of the continuous type and the alcoholic liquid is added at a rate equal to the rate of removal of the vinegar formed. This method is very efficient as $90-98 \%$ of the alcohol gets converted to acetic acid (vinegar). As for the disadvantages of the method, it needs filtration to ensure that bacteria are separated and removed from the liquid, unlike the previous two methods, as the bacteria remain either attached to the sticky layer on the surface of the liquid or adhered to sawdust. Although making acetic acid chemically is very easy, vinegar produced by microorganisms has properties and advantages related to flavor, taste and taste due to the presence of other materials that result from the fermentation process on it, so making vinegar by microbial methods could not be replaced by chemical methods (Jannah et al., 2020).

\section{Acetic acid bacteria (AAB)}

It is a Gram-negative bacteria and a forced aerobic bacterium that are unable to form spores, which can be eliminated through the process of pasteurization. These bacteria are characterized by their tolerance of high acidity, but with a lower percentage of lactic acid bacteria (Niamah et al., 2017). These bacteria are naturally present in the air, and could be isolated from damaged fruits, unpasteurized beer and apple juice, and it grows on the surface because it is an obligatory aerobic bacterium (Solieri and Giudici, 2009). These bacteria can oxidize ethanol to acetic acid. Acetic acid bacteria belong to the Acetobacteraceae family, which includes many genera and species. Currently, it is categorized into nineteen genera, including

Endobacter, Gluconacetobacter, Gluconobacter, Granulibacter Komagataeibacter, the main species responsible for vinegar production belongs to the genera Acetobacter, Gluconacetobacter, Gluconobacter and Komagataeibacter due to their high ability to oxidize ethanol to acetic acid and their ability to withstand high concentrations of acetic acid produced in the fermentation medium. The most common types of AAB used for vinegar production are Acetobacter aceti, Acetobacter cerevisiae, Acetobacter malorum, Acetobacter oeni, Acetobacter pasteurianus, Acetobacter pomorum, Gluconacetobacter entanii, Gluconacetobacter liquefaciens, Gluconobacter oxydans, Komagataeibacter europaeus, Komagataeibacter hansenii, Komagataeibacter intermedius, Komagataeibacter medellinensis, Komagataeibacter oboediens, Komagataeibacter xylinus. Its optimum growth temperature ranges between $25-30^{\circ} \mathrm{C}$. The optimum $\mathrm{pH}$ for their growth is 5- 6.5, but they can also grow at lower pH values (Gomes et al., 2018).

\section{Metabolism of acetic acid bacteria}

These bacteria oxidize ethanol by using the citric acid cycle enzymes. Initially, the alcohol is dehydrogenated to form acetaldehyde and two hydrogen ions by the enzyme Alcohol dehydrogenase $(\mathrm{ADH})$ and two electrons are released. In the second step, the hydrogen ion binds with oxygen to form water, which binds with acetaldehyde to form aldehyde. During the third step, the enzyme Aldehyde dehydrogenase (ALDH), which converts acetaldehyde into acetic acid, releases two hydrogen ions and two electrons (Figure 4) (Lynch et al., 2019; Tan, 2005).

\section{$\mathrm{CH}_{3} \mathrm{CH}_{2} \mathrm{OH}$}

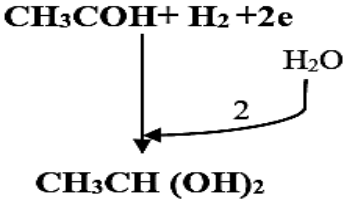

Electron transfer of cytochrome system

$$
4 \mathrm{H}+4 \mathrm{e}+2 \mathrm{O}_{2}
$$

Figure 4 Chemical equation showing conversion of ethanol to acetic acid. (1) Alcohol dehydrogenase, (2) Aldehyde dehydrogenase

\section{CONCLUSIONS}

There are several species and strains of microorganisms that could be used for the production of bioethanol. However, its production depends upon the type of microbial strain, industrial robustness, substrate utilization, productivity and yield percentage. Yeasts have been considered as the best industrial bio-catalyst for the production of bioethanol. However, in case of bacterial species; apart from $S$. cerevisiae, Z. mobilis have also been counted as a promising source for the production of bioethanol This bacterium is a naturalistic ethnologic and has several 
eligible processing biocatalyst properties, such as high specific productivity, high alcohol percentage tolerance, a wide $\mathrm{pH}$ range for production $(\mathrm{pH} 3.5-7.5)$, and most importantly it is regarded as safe bacteria. The agricultural wastes are bestutilized substrate for ethanol production. Needs to be removed from here, already discussed.

\section{REFERENCES}

Abdel-Shafy, H. I., \& Mansour, M. S. (2018). Solid waste issue: Sources, composition, disposal, recycling, and valorization. Egyptian journal of petroleum, 27(4), 1275-1290. https://doi.org/10.1016/j.ejpe.2018.07.003.

Acharya, R. N., \& Perez-Pena, R. (2020). Role of Comparative Advantage in Biofuel Policy Adoption in Latin America. Sustainability, 12(4), 1411 https://doi.org/10.3390/su12041411.

Bai, F. W., Anderson, W. A., \& Moo-Young, M. (2008). Ethanol fermentation technologies from sugar and starch feedstocks. Biotechnology advances, 26(1), 89105 https://doi.org/10.1016/j.biotechadv.2007.09.002.

Baratti, J. C., \& Bu'Lock, J. D. (1986). Zymomonas mobilis: a bacterium for ethanol production. Biotechnology advances, 4(1), 95-115. https://doi.org/10.1016/07349750(86)90006-6

Basso, T. O., Walker, R. S., Basso, L. C., Walker, G. M., Treichel, H., Alves Jr, S. L., ... \& Müller, C. (2019). The future of bioethanol. In Ethanol as a green alternative fuel: insight and perspectives (pp. 259-283). Nova Science Publishers, Inc.

Bhat, S. V., Akhtar, R., \& Amin, T. (2014). An overview on the biological production of vinegar. International Journal of Fermented Foods, 3(2), 139-155 https://doi.org/10.5958/2321-712X.2014.01315.5.

Bochner, B., Gomez, V., Ziman, M., Yang, S., \& Brown, S. D. (2010). Phenotype microarray profiling of Zymomonas mobilis ZM4. Applied biochemistry and biotechnology, 161(1-8), 116-123 https://doi.org/10.1007/s12010-009-8842-2.

Boumba, V. A., Ziavrou, K. S., \& Vougiouklakis, T. (2008). Biochemical pathways generating post-mortem volatile compounds co-detected during forensic ethanol analyses. Forensic science international, 174(2-3), 133-151 https://doi.org/10.1016/j.forsciint.2007.03.018

Calleja, G. B., Levy-Rick, S., Lusena, C. V., Nasim, A., \& Moranelli, F. (1982) Direct and quantitative conversion of starch to ethanol by the yeas Schwanniomyces alluvius. Biotechnology Letters, 4(8), 543-546 https://doi.org/10.1007/BF00131579.

Caputi, A., Ueda, M., \& Brown, T. (1968). Spectrophotometric determination of ethanol in wine. American Journal of Enology and Viticulture, 19(3), 160-165.

Cazetta, M. L., Celligoi, M. A. P. C., Buzato, J. B., \& Scarmino, I. S. (2007) Fermentation of molasses by Zymomonas mobilis: Effects of temperature and sugar concentration on ethanol production. Bioresource technology, 98(15), 2824-2828. https://doi.org/10.1016/j.biortech.2006.08.026.

Chandra, I., Abha, S., Bandyopadhyay, K. K., Shruti, S., Priya, P., Prachi, J., \& Shubha, D. (2013). Bioethanol production by Zymomonas mobilis MTCC No. 2427 using orange peels as low cost substrates. Int J ChemTech Res, 5(6), 2787 92.

Choi, J. H., Jang, S. K., Kim, J. H., Park, S. Y., Kim, J. C., Jeong, H., ... \& Choi, I. G. (2019). Simultaneous production of glucose, furfural, and ethanol organosolv lignin for total utilization of high recalcitrant biomass by organosolv pretreatment. Renewable https://doi.org/10.1016/j.renene.2018.05.052.

Conway, T. (1992). The Entner-Doudoroff pathway: history, physiology and molecular biology. FEMS microbiology reviews, 9(1), 1-27 https://doi.org/10.1111/j.1574-6968.1992.tb05822.x

Curry, A. S., Walker, G. W., \& Simpson, G. S. (1966). Determination of ethanol in blood by gas chromatography. Analyst, 91(1088), 742-743 https://doi.org/10.1039/an9669100742.

de Moraes, M. A. F. D., \& Zilberman, D. (2014). Production of ethanol from sugarcane in Brazil: from state intervention to a free market (Vol. 43). Springer Science \& Business Media.. https://doi.org/10.1007/978-3-319-03140-8

Deanda, K., Zhang, M. I. N., Eddy, C., \& Picataggio, S. (1996). Development of an arabinose-fermenting Zymomonas mobilis strain by metabolic pathway engineering. Applied and Environmental Microbiology,62(12), 4465-4470. https://doi.org/10.1128/aem.62.12.4465-4470.1996.

Demirbas, A. (2009). Political, economic and environmental impacts of biofuels: A review. Applied energy, 86, S108-S117 https://doi.org/10.1016/j.apenergy.2009.04.036

Dien, B. S., Cotta, M. A., \& Jeffries, T. W. (2003). Bacteria engineered for fuel ethanol production: status. Applied microbiology and biotechnology, 63(3), 258266 https://doi.org/10.1007/s00253-003-1444-y.

Farkas, C., Rezessy-Szabó, J. M., Gupta, V. K., Bujna, E., Csernus, O., Nguyen, V. D., ... \& Thakur, V. K. (2020). Application of chitosan-based particles for deinking of printed paper and its bioethanol fermentation. Fuel, 280, 118570 https://doi.org/10.1016/j.fuel.2020.118570.

Fonseca, G. G., Heinzle, E., Wittmann, C., \& Gombert, A. K. (2008). The yeast Kluyveromyces marxianus and its biotechnological potential. Applied microbiology and biotechnology, 79(3), 339-354. https://doi.org/10.1007/s00253 008-1458-6.

Gomes, R. J., Borges, M. D. F., Rosa, M. D. F., Castro-Gómez, R. J. H., \& Spinosa W. A. (2018). Acetic acid bacteria in the food industry: Systematics, characteristics and applications. Food technology and biotechnology, 56(2), 139-151. https://doi.org/10.17113/ftb.56.02.18.5593

Guo, X. X. (2003). Study of Aging and Production of Wine from Grape Fruit by Fermentation Process. Ethnobotanical Leaflets, 2005(1), 4.

Gupta, J., Wilson, B. W., \& Vadlani, P. V. (2016). Evaluation of green solvents for a sustainable zein extraction from ethanol industry DDGS. Biomass and Bioenergy, 85, 313-319 https://doi.org/10.1016/j.biombioe.2015.12.020.

Halstead, F. D., Rauf, M., Bamford, A., Wearn, C. M., Bishop, J. R., Burt, R., .. \& Webber, M. A. (2015). Antimicrobial dressings: Comparison of the ability of a panel of dressings to prevent biofilm formation by key burn wound pathogens. Burns, 41(8), 1683-1694 https://doi.org/10.1016/j.burns.2015.06.005. Hoogendoorn, A., \& van Kasteren, H. J. (2010). Transportation biofuels: novel pathways for the production of ethanol. Royal Society of Chemistry.

Horn, C. H., Du Preez, J. C., \& Kilian, S. G. (1992). Fermentation of grain sorghum starch by co-cultivation of Schwanniomyces occidentalis and Saccharomyces cerevisiae. Bioresource technology, 42(1), 27-31. https://doi.org/10.1016/0960 8524(92)90084-B

Huang, H., Qureshi, N., Chen, M. H., Liu, W., \& Singh, V. (2015). Ethanol production from food waste at high solids content with vacuum recovery technology. Journal of Agricultural and Food Chemistry, 63(10), 2760-2766 https://doi.org/10.1021/jf5054029

Jannah, S. N., Purwantisari, S., Handayani, D., Hartati, I., \& Yulianto, M. E. (2020, April). Production of coco-vinegar in a bubble biofermentor. In Journal of Physics: Conference Series (Vol. 1524, No. 1, p. 012066). IOP Publishing https://doi.org/10.1088/1742-6596/1524/1/012066.

Jwad, M. K. M. M. K. M., \& AI-Haidari, S. H. J. S. H. J. (2017). The Effect of Flocculation on The ethanolic Production in Some Various Yeast. Ibn AL-Haitham Journal For Pure and Applied Science, 21(4), 19-30 http://mracpc.uobaghdad.edu.iq/jih/index.php/j/article/view/1424

Kamini, N. R., \& Gunasekaran, P. (1987). Simultaneous ethanol production from lactose by Kluyveromyces fragilis and Zymomonas mobilis. Current Microbiology, 16(3), 153-157 https://doi.org/10.1007/BF01568395

Korkie, L. J., Janse, B. J. H., \& Viljoen-Bloom, M. (2002). Utilising grape pomace for ethanol production. South African Journal of Enology and Viticulture, 23(1), 31-36 https://doi.org/10.21548/23-1-2152

Kuda, T., Yazaki, T., Takahashi, H., \& Kimura, B. (2013). Effect of dried and vinegar flavored squid products on acid resistance of Salmonella Typhimurium and Staphylococcus aureus. Food control, 30(2), 569-574 https://doi.org/10.1016/j.foodcont.2012.09.011.

Kumar, A., Jain, K. K., \& Singh, B. (2020). Process optimization for chemical pretreatment of rice straw for bioethanol production. Renewable Energy https://doi.org/10.1016/j.renene.2020.04.052

Kumar, S., Moorthy, G., Rajeswari, R., \& Harikrishnan, H. (2011). Utilization of waste ripe Banana, and peels for Bio ethanol production using Saccharomyces cerevisiae. Journal of Bioscience Research, 2(2), 67-71.

Kumari, D., \& Singh, R. (2018). Pretreatment of lignocellulosic wastes for biofuel production: a critical review. Renewable and Sustainable Energy Reviews, 90 877-891 https://doi.org/10.1016/j.rser.2018.03.111.

La China, S., Zanichelli, G., De Vero, L., \& Gullo, M. (2018). Oxidative fermentations and exopolysaccharides production by acetic acid bacteria: a mini review. Biotechnology letters, 40(9-10), https://doi.org/10.1007/s10529-018-2591-7.

Leung, D. Y., Wu, X., \& Leung, M. K. H. (2010). A review on biodiesel production using catalyzed transesterification. Applied energy, 87(4), 1083-1095 https://doi.org/10.1016/j.apenergy.2009.10.006.

Li, G., Li, J., Li, S., Zu, X., Zhang, L., Qi, L., \& Xu, W. (2017). Extraction of bioethanol from fermented sweet sorghum bagasse by batch distillation. Korean Journal of Chemical Engineering, 34(1), 127-132 https://doi.org/10.1007/s11814$\underline{016-0226-\mathrm{Z}}$

Logsdon, J.E. (2004). Ethanol Kirk-othmer Encyclopedia of chemical Technology,1-35.

https://doi.org/10.1002/0471238961.0520080112150719.a01.pub2

Louhichi, B., Belgaib, J., \& Hajji, N. (2013). Production of bio-ethanol from three varieties of dates. Renewable energy, 51, 170-174. https://doi.org/10.1016/j.renene.2012.07.028

Lynch, K. M., Zannini, E., Wilkinson, S., Daenen, L., \& Arendt, E. K. (2019). Physiology of acetic acid bacteria and their role in vinegar and fermented beverages. Comprehensive Reviews in Food Science and Food Safety, 18(3), 587 625 https://doi.org/10.1111/1541-4337.12440

Manoochehri, H., Hosseini, N. F., Saidijam, M., Taheri, M., Rezaee, H., \& Nouri, F. (2020). A review on invertase: Its potentials and applications. Biocatalysis and Agricultural Biotechnology, 101599 https://doi.org/10.1016/j.bcab.2020.101599. Margaritis, A., \& Bajpai, P. (1982). Direct fermentation of D-xylose to ethanol by Kluyveromyces marxianus strains. Applied and environmental microbiology, 44(5), 1039-1041. 
Mas, A., Torija, M. J., García-Parrilla, M. D. C., \& Troncoso, A. M. (2014). Acetic acid bacteria and the production and quality of wine vinegar. The Scientific World Journal, 2014.https://doi.org/10.1155/2014/394671.

Matloob, M. H., \& Hamza, M. B. (2013). Vinegar production from low cost Iraqi dates. Journal of kerbala university, 11(3), 29-35.

Nakshoo, N. S., \& Ebrahim, A. A. (2013). Production of bioethanol using local isolate of Saccharomyces cerevisiae from raw sugar refining molasses. Damascus University Journal for the Agricultural Sciences, 29 (2), 261-271.

Niamah, A. K., Sahi, A. A., \& Al-Sharifi, A. S. (2017). Effect of feeding soy milk fermented by probiotic bacteria on some blood criteria and weight of experimental animals. Probiotics and Antimicrobial Proteins, 9(3), 284-291. https://doi.org/10.1007/s12602-017-9265-y.

Olson, D. G., Sparling, R., \& Lynd, L. R. (2015). Ethanol production by engineered thermophiles. Current Opinion in Biotechnology, 33, 130-141 https://doi.org/10.1016/j.copbio.2015.02.006.

Raharja, R., Murdiyatmo, U., Sutrisno, A., \& Wardani, A. K. (2019). Bioethanol production from sugarcane molasses by instant dry yeast. $E \& E S, 230(1), 012076$ https://doi.org/10.1088/1755-1315/230/1/012076.

Raikar, R. V. (2012). Enhanced production of Ethanol from grape waste. International Journal of Environmental Sciences,3(2), 776-783 https://doi.org/10.6088/ijes.2012030132004

Rutkis, R., Kalnenieks, U., Stalidzans, E., \& Fell, D. A. (2013). Kinetic modelling of the Zymomonas mobilis Entner-Doudoroff pathway: insights into control and functionality. Microbiology, 159(Pt_12),

https://doi.org/10.1099/mic.0.071340-0

Rutz, D., \& Janssen, R. (2007). Biofuel technology handbook. WIP Renewable energies, 95.

Seo, H. B., Kim, H. J., Lee, O. K., Ha, J. H., Lee, H. Y., \& Jung, K. H. (2009) Measurement of ethanol concentration using solvent extraction and dichromate oxidation and its application to bioethanol production process. Journal of industrial microbiology \& biotechnology, 36(2), 285-292 https://doi.org/10.1007/s10295-008-0497-4

Shah, Y. R., \& Sen, D. J. (2011). Bioalcohol as green energy-A review. Int J Cur Sci Res., 1(2), 57-62.

Shih, C. J. (2010). Determination of saccharides and ethanol from biomass conversion using Raman spectroscopy: effects of pretreatment and enzyme composition (No. IS-T 3006). Ames Laboratory (AMES), Ames, IA (United States). Paper 11596. https://doi.org/10.31274/etd-180810-909.

Soleimani, S. S., Adiguzel, A., \& Nadaroglu, H. (2017). Production of bioethano by facultative anaerobic bacteria. Journal of the Institute of Brewing, 123(3), 402406 https://doi.org/10.1002/jib.437.

Solieri, L., \& Giudici, P. (2009). Vinegars of the World. In Vinegars of the World (pp. 1-16). Springer, Milano https://dio.org/10.1007/978-88-470-0866-3.

Soto, A. F., Mendes, E. M., Arthur, R. A., de Cássia Negrini, T., Lamers, M. L., \& Mengatto, C. M. (2019). Antimicrobial effect and cytotoxic activity of vinegarhydrogen peroxide mixture: A possible alternative for denture disinfection. The Journal of prosthetic dentistry, 121(6), 966-e1 https://doi.org/10.1016/j.prosdent.2019.02.019.

Stewart, G. G., Panchal, C. J., Russell, I., \& Sills, A. M. (1983). Biology of ethanolproducing microorganisms. Critical Reviews in Biotechnology, 1(3), 161-188 https://doi.org/10.3109/07388558309077977.

Swings, J., \& De Ley, J. (1977). The biology of Zymomonas. Bacteriological reviews, $41(1), 1$

Taghizadeh-Alisaraei, A., Motevali, A., \& Ghobadian, B. (2019). Ethanol production from date wastes: Adapted technologies, challenges, and global potential. Renewable

https://doi.org/10.1016/j.renene.2019.05.048

Tan, S. C. (2005). Vinegar fermentation. Louisiana State University and Agricultural and Mechanical College 89pp.

Taouda, H., Chabir, R., Aarab, L., Miyah, Y., \& Errachich, F. (2017). Biomass and bioethanol production from date extract. J. Mater. Environ. Sci, 8(9), 3391-3396.

Tonelli, D. (2009). Methods for determining ethanol in beer. In Beer in Health and

Disease Prevention (pp. 1055-1065). Academic Press https://doi.org/10.1016/B978-0-12-373891-2.00102-4 .

Vidra, A., \& Németh, Á. (2018). Bio-produced acetic acid: A review. Periodica $\begin{array}{lll}\text { Polytechnica Chemical Engineering, 62(3), 245-256 } & \end{array}$ https://doi.org/10.3311/PPch.11004.

Wang, M. L., Choong, Y. M., Su, N. W., \& Lee, M. H. (2003). A rapid method for determination of ethanol in alcoholic beverages using capillary gas chromatography. Journal of Food and Drug Analysis, 11(2).

Yagnik, D., Serafin, V., \& Shah, A. J. (2018). Antimicrobial activity of apple cider vinegar against Escherichia coli, Staphylococcus aureus and Candida albicans downregulating cytokine and microbial protein expression. Scientific reports, $8(1)$, 1-12. https://doi.org/10.1038/s41598-017-18618-X.

Zhang, K., Lu, X., Li, Y., Jiang, X., Liu, L., \& Wang, H. (2019). New technologies provide more metabolic engineering strategies for bioethanol production in Zymomonas mobilis. Applied microbiology and biotechnology, 103(5), 2087-2099 https://doi.org/10.1007/s00253-019-09620-6.
Zohri, A. N. A., \& Etnan, M. M. (2000). Ethanol production from dates in Saudi Arabia on industrial scale. Mycobiology, 28(2), 76-81 https://doi.org/10.1080/12298093.2000.12015727. 